\title{
The Role of Nicotinic Anti-Inflammatory Pathway in Prostaglandin Mediated Inflammatory Response in Sepsis: A Short Review
}

\author{
Elif Baris $^{12}$ (D), Mualla Aylin Arici ${ }^{3}$ (D) Emre Hamurtekin ${ }^{4}$ (C) \\ ${ }^{1}$ Dokuz Eylul University, Graduate School of Health Sciences \\ ${ }^{2}$ Izmir University of Economics, Faculty of Medicine, Medical Sciences, Department of Pharmacology \\ ${ }^{3}$ Dokuz Eylul University, Faculty of Medicine, Medical Sciences, Department of Pharmacology \\ ${ }^{4}$ Eastern Mediterranean University, Faculty of Pharmacy, Department of Pharmacology \\ Correspondence Author: Elif Baris \\ E-mail: elif.baris.111@gmail.com \\ Received: $02.04 .2019 \quad$ Accepted: 16.08 .2019
}

\begin{abstract}
Sepsis is a severe and multifaceted condition of body in response to an infection, which affects multiple organs systems that makes it difficult to treat and enhances the mortality rates. Release of inflammatory cytokines can initiate an inflammatory response during sepsis. However, the response can be modified by the control mechanism inside the body that are essential for the keeping the balance and survival. The cholinergic antiinflammatory pathway is defined as a comprehensive neurohumoral pathway that diminishes pro-inflammatory cytokine release through the vagus nerve and cholinergic receptors, predominantly $\alpha 7$ nicotinic acetylcholine receptors ( $\alpha 7 \mathrm{nAChR}$ ) that expressed on inflammatory mononuclear cells. Thus, cholinergic agonists might be a part of prospective treatment approach in inflammatory diseases such as sepsis. This review covers the role of cholinergic system in prostaglandin mediated inflammatory response.

Keywords: Cholinergic anti-Inflammatory pathway, $\alpha 7 \mathrm{nAChR}$, inflammation, sepsis, prostaglandin
\end{abstract}

\section{INTRODUCTION}

Sepsis is a rigorous and multifaceted condition of body in response to an infective state, which affects multiple organs systems that makes it difficult to treat. Replacement therapies, antimicrobial agents, vasopressors, immunoglobulins, anticoagulant drugs and corticosteroids are involved in current treatment of sepsis however it is still one of the most common causes of death in hospitalized patients. On the subject of the pathophysiology of sepsis, many experimental studies have been conducted in last few decades. A good part of these researches focused on the nicotinic anti-inflammatory pathway that plays a crucial role in the control of inflammatory response. This review summarizes the role of cholinergic agonists and their impact on sepsis pathophysiology.

Sepsis is defined as the systemic inflammatory response to infection, and microbial pathogens and inflammatory response are involved in its physiopathology. Primary cause of sepsis is initiation of inflammation by microbial agent and progression of inflammatory state leads a condition called severe sepsis, which is a common cause of mortality in intensive care units. This condition is commenced with the overproduction of inflammatory cytokines that leads systemic inflammation, extensive hypotension and consequently multiple organ damage (1).
Macrophages, dendritic cells, B lymphocytes are antigen presenting cells (APCs) that modifies antigenic structures into small peptide molecules that can be recognized by T-cell surface receptors like antigen-specific CD8+ in case of inflammation and initiate the primary inflammatory response $(2,3)$.

Regarding that lipopolysaccharide (LPS) is an endotoxin of gram-negative bacteria; exposure of LPS can initiate a compelling inflammatory response. Lipid A compartment of lipopolysaccharide can interact with toll like receptors on phagocytic mononuclear cells. These cells releases tumor necrosis factor (TNF), interleukins, platelet activating factor (PAF) as a response to the inflammatory state (4). IL- 1 and IL- 6 mediates the activation of T cells and release of cytokines such as a-interferon, IL-2, IL-4, granulocytemacrophage colony-stimulating factor (GM-CSF). These cytokines are useful in the renewal of the local inflammation and tissue regeneration however greater release of them into blood circulation results in widespread endothelial cell damage. Among the released cytokines, TNF can activate adhesion molecules on the surface of leukocytes and cause the neutrophil adhesion onto endothelial cells. Proteases and reactive oxygen species freed from stimulated neutrophils ease the endothelial cell damage. Endothelial impairment is the beginning of hemodynamic changes in sepsis that eventually leads hypotension, organ failure and mortality. Arachidonic acid metabolites; prostaglandins and 
leukotrienes can cause an increase in capillary permeability, which can be produced with the direct effect of endotoxins or cytokines which also contribute the inflammatory response $(5,6)$. Since the release of numerous kinds of cytokines occur in case of sepsis, treatment strategies may involve the diminution of different kinds of cytokines rather than single one in order to be successful. With respect to this aspect, agents that modulate the cholinergic anti-inflammatory pathway come into prominence in the last decade.

\section{Cholinergic System and Inflammatory Response}

Release of inflammatory cytokines can trigger an inflammatory response. However, the response can be controlled by the control mechanism inside the body that are essential for the keeping the balance and survival. This control mechanism on inflammation can be achieved by two mechanisms; activation of neuronal and non-neuronal cholinergic system $(4,7)$. Neuronal cholinergic system involves triggering the vagus nerve whereas non-neuronal cholinergic system activation comprises nicotinic receptor activation expressed on cells that contribute inflammation such as lymphocytes, macrophages, mast cells, dendritic cells, basophils, microglia (8-10).

The cholinergic anti-inflammatory pathway is defined as a comprehensive neural mechanism that attenuates pro-inflammatory cytokine release through the vagus nerve and cholinergic receptors, predominantly $\alpha 7$ nicotinic acetylcholine receptors ( $\alpha 7 n A C h R)$. These are homopentameric receptors of cholinergic nicotinic acetylcholine receptor family that composes of five $\alpha 7$ subunits and acetylcholine binding sites. Nicotinic acetylcholine receptors are ligand gated ion channels that characterized as their permeability to sodium ion upon the receptor activation, however $\alpha 7 \mathrm{nAChR}$ are highly permeable for calcium influx. Increments of intracellular calcium ion may trigger many signaling cascades that are required for communication between cholinergic nerves and the immune system. It has been shown that $\alpha 7$ nicotinic acetylcholine receptors are expressed on mononuclear cells of immune system and especially macrophages takes a part in the antiinflammatory action of cholinergic system. For that reason, this pathway is also called a nicotinic anti-inflammatory pathway. $(4,11,12)$.

Liberation of inflammatory cytokines during an inflammatory response can stimulate brain in order to activate cholinergic anti-inflammatory pathway. The activation of pathway occurs in two ways. One of them is afferent vagus nerve stimulation by the inflammatory cytokines released by activated inflammatory cells via inflammatory stimulus (13). Another way is the passage of cytokines to brain via the transporters on blood brain barrier or through circumventricular organs (14). Cytokines can interact with the capillary endothelium of brain and induce the production of prostaglandins, which in turn may cause fever, pain and the production of glucocorticoids via hypothalamus-pituitary-adrenal (HPA) axis activation $(15,16)$. In response of stimulation via the inflammatory cytokines, brain activates the hypothalamuspituitary-adrenal (HPA) axis to generate glucocorticoids, sympathetic nervous system to generate catecholamine and efferent vagus nerve for the release of acetylcholine. Acetylcholine that released from the vagal nerve terminals is induced the splenic nerve that results in the discharge of norepinephrine (NE). T lymphocytes are abundant in spleen and beta-adrenergic receptors expressed on the cell surface can be triggered via the NE released from splenic nerve in order to release acetylcholine. Consecutively $\alpha 7 n A C h R$ receptors on macrophage surface is activated by acetylcholine. As a result an effective immunomodulatory action is produced $(7,17)$.

Pertaining to the role of cholinergic system in inflammation, many experimental studies have been conducted in last decades. The role of cholinergic agonists such as nicotine, choline, phosphatidylcholine, CDP-choline in inflammatory conditions like inflammatory bowel diseases, pancreatitis, sepsis, arthritis have been investigated with animal models and clinical researches (18-23). Supporting data has been observed that stimulation of the vagus nerve moderates the inflammatory response by triggering of cholinergic antiinflammatory pathway in endotoxemic animals $(10,24,25)$. In another study, electrical stimulation of the vagus nerve has been shown to increase acetylcholine release and decrease TNF- $\alpha$ levels through $\alpha 7 n A C h R s$ in experimental sepsis model in mice $(24,26)$. However, electrical stimulation of vagus nerve has been unsuccessful to reduce inflammatory mediators in case of splenic nerve injury or splenectomized mice supports the role of spleen in anti-inflammatory effect of cholinergic system (27).

These findings bear the idea out that vagus nerve has a control over inflammation via the $\alpha 7 \mathrm{nAChR}$. As well as the physiological approaches, pharmacologic interventions especially drugs act on $\alpha 7 n A C h R s$ have been investigated in quite a lot of studies to activate the cholinergic system.

\section{Cholinergic Agonist and Sepsis}

As a cholinergic agonist choline was first synthesized in 1966 and since 1998, it has been considered as an essential substance for life. Choline is a precursor in the synthesis of neurotransmitter acetylcholine in the body and at high doses it can directly interacts with acetylcholine receptors. As a result, cholinergic neurotransmission is enhanced by administration of choline. Furthermore, choline also contributes the synthesis of some basic phospholipids such as phosphatidylcholine and sphingomyelin, which are the basic building blocks of cell membrane (28).

Citicoline (CDP-choline, Cytidine 5'-diphosphate choline) is a complex organic molecule that is produced endogenously as an intermediate molecule in the de novo synthesis of cell membrane phospholipids. Collected evidence supports the cholinergic and neuroprotective effects of administration of citicoline. Citicoline is quickly hydrolyzed into choline 
and cytidine by the membrane phosphodiesterases when exogenously administered (29). Accordingly, choline levels in the brain and blood circulation increases (30-32). Choline enhances acetylcholine synthesis $(32,33)$ and its release into synaptic cleft $(34,35)$. Citicoline-mediated improved sympathetic and cholinergic system activity leads many pharmacological and physiological effects $(31,32,36)$. Moreover, the beneficial effect of citicoline given as a nutritional supplement has been observed to the structural integrity and functionality of the neuronal membrane (37). Therefore, in clinical cases citicoline supplements are recommended in cerebral ischemia, hypoxia, head trauma, learning and memory development, Alzheimer's disease, cognitive disorders and Parkinson's disease (34,38-42).

Since their impact on the increment in cholinergic signaling and interaction with the $\alpha 7 n A C h R$; the role of choline and citicoline in inflammation are investigated in several studies (43-46). GTS-21, a $\alpha 7 n A C h R$ agonist, has been shown to decrease cytokine levels in inflammatory conditions and improve survival rates in sepsis induced by cecal ligation and puncture (47-49). Many studies have shown that citicoline and choline increase survival rates (50-53) and exert positive effects on tissue damage and multiple organ failure in endotoxemic animals $(51,53,54)$.

Many studies have shown that citicoline and choline increase survival rates and exert positive effects on tissue damage and multiple organ failure in endotoxemic animals (50-54). Since the cardiovascular system dysfunctions during sepsis is one of the most affected organ systems in sepsis and the main cause of multiple organ failure; there are plenty of studies investigates the effect of citicoline on cardiovascular changes $(32,36,55,56)$. It has been shown that citicoline and choline have a positive effect on disrupted secondary hemostatic and fibrinolytic systems, disseminated intravascular coagulation and the consumption of increased coagulation factors in the LPS-induced septic shock model (45). Citicoline has been shown to regulate microvascular permeability, hemodynamic and inflammatory parameters while improving the hypotension in septic shock $(57,58)$.

In addition to their cardiovascular effects, cholinergic agonists, choline and citicoline, display a protective effect on vital organs in case of sepsis. Choline reduces endotoxininduced increase of serum proteins, lipids and inflammatory mediators via the vagal anti-inflammatory pathway activation and endotoxin-induced mononuclear cell activation $(46,58)$. In another study, intraperitoneal administration of choline have been reduced TNF- $\alpha$ level in macrophage cell culture and endotoxemic mice. However, modulating TNF- $\alpha$ level was unsuccessful in $\alpha 7 n A C h R$ knock-out mice and the requirement of $\alpha 7 n A C h R$ in the anti-inflammatory action of choline have been supported $(7,50,59)$.

\section{Proposed Mechanisms of Cholinergic Agonists in Sepsis}

The effects of choline and other $\alpha 7 n A C h R$ agonists on inflammatory response have been investigated by in-vitro studies using RAW264.7 macrophage cell line. Choline and $\alpha 7 n A C h R$ agonist GTS-21 produced a significant reduction in TNF- $\alpha$ and HMGB-1 levels in endotoxin-activated RAW264.7 macrophages $(47,50,60)$. However, the effects of cholinergic agonists GTS-21 and NS6740, weak agonist of $\alpha 7 \mathrm{nAChR}$, have been vanished when selective antagonist methyllycaconitine is applied to LPS-activated microglial culture (61). Administration of cholinergic neurotransmitter acetylcholine caused a significant reduction in the level of proinflammatory cytokines such as TNF- $\alpha$, IL-1 $1 \beta$, IL- 6, IL-18 and HMGB1 in lipopolysaccharide-activated human macrophage cells emphasizing that nicotinic receptor activation may be a potential pharmacological target in the treatment of sepsis $(10,11,48,62)$.

Since the cells that contribute the inflammatory response have been found to express cholinergic receptors; their contributions to cholinergic inflammatory response have been widely examined. It has been established expression of $\alpha 7 n A C h R s$ on T lymphocytes, B lymphocytes, dendritic cells, monocytes, macrophages and microglial cells $(61,63-$ 67). T lymphocytes and microglial cells also show choline acetyltransferase and acetylcholinesterase activity as well $(64,68)$. In other words these cells can be affected by cholinergic transmission. It has been showed that acetylcholine may have an impact on $\mathrm{T}$ cells. Studies have been emphasized that stimulation of nicotinic receptors on T cells with nicotine or acetylcholine can affect intracellular calcium concentration and eventually intracellular signaling cascades have been activated $(64,69,70)$.

Since $\alpha 7 n A C h R s$ are ion gated calcium channels that receptor activation may cause an inward of calcium into cells and rapid desensitization via the change in electrochemical gradient. At the molecular level increase in intracellular calcium concentration activates inositol-triphosphate and phospholipase $\mathrm{C}$ that cause calcium release from cellular storages and triggers calcium dependent signaling pathways such as ERK/MAPK in neurons and astrocytes (71,72). However quite a few studies has also been shown that of cholinergic anti-inflammatory pathways may be independent from calcium ion passing through the $\alpha 7 n A C h R(47,50,73,74)$. Studies employing whole patch-clamp technique reveals that leukocytes, as one of the mononuclear cells, have failed to establish $\alpha 7 n A C h R-m e d i a t e d$ changes in electrical current $(75,76)$. Apart from that recent studies have been found the dual action of $\alpha 7 n A C h R$ underlining that $G$ proteins might also have a role in inositol-triphosphate induced calcium release and metabotropic action of this receptor (Figure 1) $(77,78)$. 


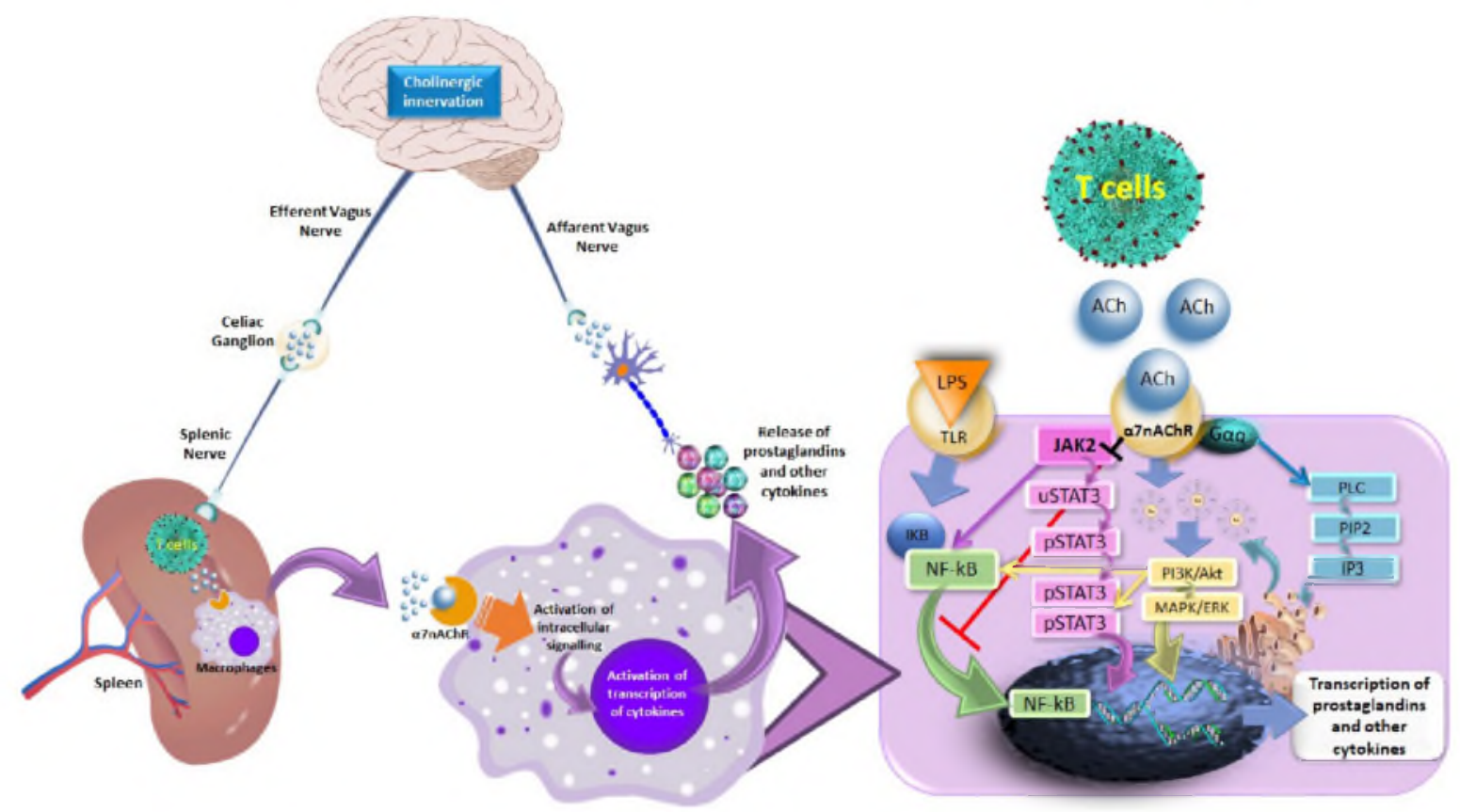

Figure 1: The neurohumoral mechanism activated during inflammatory challenge and the role of $\alpha 7 n A C h R$ mediated anti-inflammatory response. During LPS induced inflammatory response, ACh released from activated T cells stimulates the $\alpha 7 n A C h R s$ on macrophages which in turn diminishes the proinflammatory cytokine release such as prostaglandins via interfering the intracellular signaling pathways (red arrows indicates the inhibitory action) (details are given in text).

Regarding the $\alpha 7 \mathrm{nAChR}$ mediated inhibition of proinflammatory cytokines in macrophages, two proposed molecular mechanisms is prominent among the others; inhibiting the nuclear translocation of transcription factor NF-KB and JAK2 / STAT3 signaling pathway $(67,79,80)$. a7nAChR agonist nicotine elevates AKT phosphorylation via the activation of JAK2 and PI3K upon the receptor activation and calcium influx. JAK2 and PI3K pathways both have an impact transcription factor NF-kB $(81,82)$. It has been showed that nicotine inhibits the activation of NF-kB cascade and inflammatory cytokine release via the $\alpha 7 n A C h R$ stimulation in macrophages (83). Choline and nicotine, $\alpha 7 n A C h R$ agonists, have been induced the inhibition of NF-KB and consecutive decrease in TNF alpha when administered to LPS-induced RAW 264.7 macrophage cells. Additionally, choline was failed to prevent TNF alpha release in peritonea macrophage cell culture from $\alpha 7 n A C h R$ knockout mice, supporting the role of $\alpha 7 \mathrm{nAChR}$ for the anti-inflammatory action $(50,83)$. Apart from NF-KB pathway, some studies underline the role of JAK2/STAT3 pathway regarding the anti-inflammatory effect of choline (84). Activation of JAK2 cascade results in production of an anti-inflammatory transcription factor STAT3 that involves the production of anti-inflammatory cytokines IL-6 and IL-10 $(85,86)$. Another study points out the inhibitory effect of choline on increment of LPS-induced TNF $\alpha$ levels but unsuccessful to demonstrate its efficacy in the JAK2-inhibited experimental group (87). Additionally, augmentation of COX-2, NOS expression levels and consequent increase in NO, PGE2, TNF $\alpha$, IL-6 levels in LPS-induced RAW 264.7 macrophage cells were shown to be mediated by JAK / STAT pathway (88). Taken together, a growing body of data points out that multiple intracellular cascades may be involved in anti-inflammatory action of choline and $\alpha 7 \mathrm{nAChR}$ mediators

\section{Prostaglandins and Sepsis}

As a part of the pro-inflammatory cytokine family, prostaglandins are also contributed to the inflammatory response. Formation of prostaglandins from arachidonic acid involves cyclooxygenase (COX) enzyme that has two isoforms. The COX-1 isoform mostly take a part in the formation of prostaglandins associated with the homeostasis. Oppositely, COX-2 isoform play an important role in production of cytokines induced by tissue damage, tumor promoters, inflammation and cancer. As an inducible enzyme, COX-2 expression level can be increased with cytokines in inflamed tissues that consequently leads the production of prostaglandin $\mathrm{G} 2$ (PGG2) and prostaglandin $\mathrm{H} 2$ (PGH2). $\mathrm{PGG} 2 / \mathrm{H} 2$ are precursors of other prostanoids that contribute inflammation. Prostaglandin I synthase and microsomal prostaglandin E synthase produce PGI2 and PGE2 that plays a major role in the pyretic response which is one of the main symptoms of sepsis (89). PGE2 and PGI2 increase the rate of blood flow by causing vasodilation which further facilitates signs of inflammation such as leukocyte infiltration, pain, and edema (90-94)

Studies have been shown that prostaglandin formation has been mainly related to COX-2 in the carrageenan-induced acute inflammation model $(93,95)$. Augmented expression of cyclooxygenase-2 (COX-2) has been shown in LPS induced invitro sepsis model in macrophages $(96,97)$. 
Considering the interaction between cholinergic system and cyclooxygenase pathway; citicoline, as choline donor, inhibited the activation of phospholipase $A 2$, decreased the production of arachidonic acid in necrotic tissue when administered orally (98). Acetylcholinesterase inhibitor tacrine has been inhibited the increase in COX-2 expression and PGE2 production in LPS-induced RAW macrophage cell culture by decreasing the degradation of acetylcholine (99). Conflicting results were obtained in an in-vitro study that COX2 expression and prostaglandin E2 synthesis have been shown to increase when the $\alpha 7 \mathrm{nAChR}$ selective agonist nicotine is applied to primary culture of microglial cells (68). Although it has been showed that PGE2 may have a part in reduction of microglial activation and TNF $\alpha$ production in the cerebral endothelium and brain parenchyma (100). Co-administration of choline and aspirin in carrageenan and LPS-induced acute inflammation models in mice produced a synergistic anti-inflammatory effect. In the study, it was observed that choline significantly decreased the level of inflammation induced PGE2, PGI2, TXA2 and other inflammatory cytokines. It has been emphasized that diminishing effect on prostanoid and cytokine levels is mediated by $\alpha 7 n A C h R$ activation. Taken together that cholinergic agonists might be a part of prospective treatment approach in inflammatory diseases such as sepsis and arthritis (52).

\section{CONCLUSION}

The specialized function of cholinergic system in order to produce an anti-inflammatory action in the body have been described in last few decades and cholinergic agonists have been widely investigated to modulate the release of inflammatory cytokines. As a part of the cytokine family prostaglandins are one of the main contributors of the cardinal signs of inflammation. Further investigations on the control of cholinergic anti-inflammatory pathway in the release of prostaglandins may provide us a novel treatment strategy in case of inflammatory response syndrome and sepsis.

\section{REFERENCES}

[1] Rice TW, Bernard GR. Therapeutic Intervention and Targets for Sepsis. Annu Rev Med 2005;56(1):225-248.

[2] Redwine JM, Buchmeier MJ, Evans CF. In vivo expression of major histocompatibility complex molecules on oligodendrocytes and neurons during viral infection. Am J Pathol 2001;159(4):1219-1224.

[3] KatzungBG,Kruidering-HallM, TrevorAJ.Immunopharmacology Katzung \&amp; Trevor's Pharmacology: Examination \&amp; Board Review, 12e. New York, NY: McGraw-Hill Education; 2019.

[4] Ulloa L. The vagus nerve and the nicotinic anti-inflammatory pathway. Nat Rev Drug Discov 2005;4:673.

[5] Stearns-Kurosawa DJ, Osuchowski MF, Valentine C, Kurosawa S, Remick DG. The pathogenesis of sepsis. Annu Rev Pathol 2011;6:19-48.
[6] Gotts JE, Matthay MA. Sepsis: pathophysiology and clinical management. BMJ 2016;353:i585.

[7] Remick DG. Pathophysiology of sepsis. Am J Pathol 2007;170(5):1435-1444.

[8] Pavlov VA, Wang H, Czura CJ, Friedman SG, Tracey KJ. The cholinergic anti-inflammatory pathway: a missing link in neuroimmunomodulation. Mol Med 2003;9(5-8):125-134.

[9] Fujii T, Mashimo M, Moriwaki Y, Misawa H, Ono S, Horiguchi K, Kawashima K. Expression and Function of the Cholinergic System in Immune Cells. Frontiers in Immunology 2017;8:1085.

[10] Snider SA, Margison KD, Ghorbani P, LeBlond ND, O'Dwyer C, Nunes JRC, Nguyen T, Xu H, Bennett SAL, Fullerton MD. Choline transport links macrophage phospholipid metabolism and inflammation. J Biol Chem 2018;293(29):11600-11611.

[11] Borovikova L V, Ivanova S, Zhang $M$, Yang $H$, Botchkina $G I$, Watkins LR, Wang H, Abumrad N, Eaton JW, Tracey KJ. Vagus nerve stimulation attenuates the systemic inflammatory response to endotoxin. Nature 2000;405:458.

[12] Tarnawski L, Reardon C, Caravaca AS, Rosas-Ballina M, Tusche MW, Drake AR, Hudson LK, Hanes WM, Li JH, Parrish WR, Ojamaa K, Al-Abed Y, Faltys M, Pavlov VA, Andersson U, Chavan SS, Levine YA, Mak TW, Tracey KJ, Olofsson PS. Adenylyl Cyclase 6 Mediates Inhibition of TNF in the Inflammatory Reflex. Front Immunol 2018;9:1-8.

[13] De Jonge WJ, Ulloa L. The alpha7 nicotinic acetylcholine receptor as a pharmacological target for inflammation. $\mathrm{Br} J$ Pharmacol 2007;151(7):915-929.

[14] Banks W, J. Kastin A, D. Broadwell R. Passage of Cytokines across the Blood-Brain Barrier. Neuroimmunomodulation 1995;2:241-248.

[15] Buller K. Role of circumventricular organs in pro-inflammatory cytokine-induced activation of the hypothalamic-pituitaryadrenal axis. Clin Exp Pharmacol Physiol 2001;28:581-589.

[16] Tassorelli C, Greco R, Armentero MT, Blandini F, Sandrini G, Nappi GBT-IR of N. A Role for Brain Cyclooxygenase-2 and Prostaglandin-E2 in Migraine: Effects of Nitroglycerin. Neuroinflammation in Neuronal Death and Repair 2007;82:373-382.

[17] Rivest S. How circulating cytokines trigger the neural circuits that control the hypothalamic-pituitary-adrenal axis. Psychoneuroendocrinology 2001;26(8):761-788.

[18] Kanashiro A, Sônego F, Ferreira RG, Castanheira FV, Leite CA, Borges VF, Nascimento DC, Cólon DF, Alves-Filho JC, Ulloa L, Cunha FQ. Therapeutic Potential and Limitations of Cholinergic Anti-Inflammatory Pathway in Sepsis. Pharmacological research 2017;117:1-8.

[19] McGrath J, McDonald JWD, MacDonald JK. Transdermal nicotine for induction of remission in ulcerative colitis. Cochrane Libr 2004;18;(4):CD004722.

[20] Aldhous M, Prescott R, Roberts S, Samuel K, Waterfall M, Satsangi J. Does Nicotine Influence Cytokine Profile and Subsequent Cell Cycling/Apoptotic Responses in Inflammatory Bowel Disease? Inflammatory bowel diseases 2008;14:14691482.

[21] Sagami S, Ueno Y, Tanaka S, Fujita A, Niitsu H, Hayashi R, Hyogo $\mathrm{H}$, Hinoi T, Kitadai Y, Chayama K. Choline Deficiency Causes Colonic Type II Natural Killer T (NKT) Cell Loss and Alleviates Murine Colitis under Type I NKT Cell Deficiency. PLoS One 2017;12(1):e0169681-e0169681. 
[22] Gorelick F, Lerch M. Do Animal Models of Acute Pancreatitis Reproduce Human Disease? Cell Mol Gastroenterol Hepato 2017;4:251-262.

[23] Treede I, Braun A, Sparla R, Kühnel M, Giese T, Turner JR, Anes E, Kulaksiz H, Füllekrug J, Stremmel W, Griffiths G, Ehehalt R. Anti-inflammatory effects of phosphatidylcholine. J Biol Chem. 2007;282(37):27155-27164.

[24] Hartmann P, Szabó A, Eros G, Gurabi D, Horváth G, Németh I, Ghyczy M, Boros M. et al. Anti-Inflammatory Effects of Phosphatidylcholine in Neutrophil Leukocyte-Dependent Acute Arthritis in Rats. Eur J Pharmacol 2009;622:58-64.

[25] Wang $H$, Yu M, Ochani M, Amella CA, Tanovic M, Susarla S, Li JH, Wang H, Yang H, Ulloa L, Al-Abed Y, Czura CJ, Tracey KJ. Nicotinic Acetylcholine Receptor alpha7 Subunit Is an Essential Regulator of Inflammation. Nature 2003;421:384-388.

[26] Zhao $Y X, H e ~ W$, Jing $X H$, Liu JL, Rong PJ, Ben H, Liu K, Zhu B. Transcutaneous auricular vagus nerve stimulation protects endotoxemic rat from lipopolysaccharide-induced inflammation. Evid Based Complement Alternat Med 2012;2012:627023.

[27] Bernik TR, Friedman SG, Ochani M, DiRaimo R, Ulloa L, Yang H, Sudan S, Czura CJ, Ivanova SM, Tracey KJ. et al. Pharmacologica stimulation of the cholinergic antiinflammatory pathway. J Exp Med 2002;195(6):781-788.

[28] Huston J, Ochani M, Rosas-Ballina M, Liao H, Ochani K, Pavlov VA, Gallowitsch-Puerta M, Ashok M, Czura CJ, Foxwell B, Tracey $\mathrm{KJ}$, Ulloa L. et al. Splenectomy Inactivates the Cholinergic Antiinflammatory Pathway during Lethal Endotoxemia and Polymicrobial Sepsis. Shock 2006;25:1623-1628.

[29] Ulus IH, Cansev M. Kolin'in Merkezi ve Periferik Kolinerjik Nöronlarda ve Kolinerjik İletimdeki İşlevi. Acıbadem Üniversitesi Sağık Bilim Derg 2010;1:68-80 (in Turkish).

[30] Weiss GB. Metabolism and Actions of CDP-Choline as an Endogenous Compound and Administered Exogenously as Citicoline. Life sciences 1995;56:673-660.

[31] Ilcol Y, Cansev M, Yilmaz S, Hamurtekin E, H Ulus I. Intraperitoneal administration of CDP-choline and its cholinergic and pyrimidinergic metabolites induce hyperglycemia in rats: Involvement of the sympathoadrenal system. Arch Physiol Biochem 2007;113:186-201.

[32] Savci V, Goktalay G, Cansev M, Cavun S, Yilmaz S, H. Ulus I Intravenously injected CDP-choline increases blood pressure and reverses hypotension in haemorrhagic shock: Effect is mediated by central cholinergic activation. Eur J Pharmaco 2003;468:129-139.

[33] Cermak J, Holler T, Jackson D, Krzysztof Blusztajn J. Prenata Availability of Choline Modifies Development of Hippocampa Cholinergic System. FASEB 1998;12:349-357.

[34] Ulus IH, Hirsch MJ, Wurtman J. TransSynaptic Induction of Adrenomedullary Tyrosine Hydroxylase Activity by Choline: Evidence That Choline Administration Can Increase Cholinergic Transmission. Proceedings of The National Academy of Sciences 1997;74:798-800.

[35] Ulus IH, Scally MC, Wurtman J. Enhancement by Choline of the Induction of Adrenal Tyrosine Hydroxylase by Phenoxybenzamine, 6-Hydroxydopamine, Insulin or Exposure to Cold. The Journal of pharmacology and experimental therapeutics 1978;204:676-682.

[36] Savci V, Cavun S, Goktalay G, Ulus IH. Cardiovascular effects of intracerebroventricularly injected CDP-choline in normotensive and hypotensive animals: the involvement of cholinergic system. Naunyn Schmiedebergs Arch Pharmacol 2002;365(5):388-398.

[37] McDaniel MA, Maier SF, Einstein GO. "Brain-specific" nutrients: a memory cure? Nutrition 2003;19(11):957-975

[38] Dixon CE, Ma X, Marion DW. Effects of CDP-Choline Treatment on Neurobehavioral Deficits after TBI and on Hippocampal and Neocortical Acetlycholine Release. J Neurotrauma 1997;14(3):161-169.

[39] K. Başkaya M, Dogan A, Adibhatla R, J. Dempsey R. Neuroprotective Effects of Citicoline on Brain Edema and Blood-Brain Barrier Breakdown after Traumatic Brain Injury. J Neurosurg 2000; 92:448-452.

[40] Adibhatla R, Hatcher J, J Dempsey R. Lipid Alterations in Transient Forebrain Ischemia: Possible New Mechanisms of CDP-Choline Neuroprotection. Journal of neurochemistry 2001:75:2528-2535

[41] Qian K, Gu Y, Zhao Y, Li Z, Sun M. Citicoline Protects Brain Against Closed Head Injury in Rats Through Suppressing Oxidative Stress and Calpain Over-Activation. Neurocheml Res 2014;39:1206-1218.

[42] Hamurtekin E, Gurun M. The Antinociceptive Effects of Centrally Administered CDP-Choline on Acute pain models in rats: the involvement of cholinergic system. pain models in rats: the involvement of cholinergic system. Brain Res 2006; 1117(1):92-100.

[43] Gurun M, Parker R, C Eisenach J, Vincler M. The Effect of Peripherally Administered CDP-Choline in an Acute Inflammatory Pain Model: The Role of $\alpha 7$ Nicotinic Acetylcholine Receptor. Anesth Analg 2009;108(5):1680-1687.

[44] Yilmaz Z, IIcol Y, Cansev M, Eralp Inan O, Kocatürk M, H Ulus I. Choline or CDP-choline attenuates coagulation abnormalities and prevents the development of acute disseminated intravascular coagulation in dogs during endotoxemia. Blood Coagul Fibrinolysis 2010;21(4):339-348.

[45] Ilcol YO, Yilmaz Z, Ulus IH. Endotoxin alters serum-free choline and phospholipid-bound choline concentrations, and choline administration attenuates endotoxin-induced organ injury in dogs. Shock 2005;24(3):288-293.

[46] Pavlov VA, Ochani M, Yang LH, Gallowitsch-Puerta M, Ochani $\mathrm{K}$, Lin X, Levi J, Parrish WR, Rosas-Ballina M, Czura CJ, Larosa GJ, Miller EJ, Tracey KJ, Al-Abed Y. Selective a7-nicotinic acetylcholine receptor agonist GTS-21 improves survival in murine endotoxemia and severe sepsis. Crit Care Med 2007;35(4):1139-1144.

[47] Yeboah MM, Xue X, Javdan M, Susin M, Metz CN. Nicotinic acetylcholine receptor expression and regulation in the rat kidney after ischemia-reperfusion injury. Am J Physiol Renal Physiol 2008;295(3):F654-F661.

[48] van Westerloo DJ, Giebelen IA, Florquin S, Bruno MJ, Larosa GJ, Ulloa L, Tracey KJ, van der Poll T. et al. The Vagus Nerve and Nicotinic Receptors Modulate Experimental Pancreatitis Severity in Mice. Gastroenterology 2006;130(6):1822-1830.

[49] Parrish WR, Rosas-Ballina M, Gallowitsch-Puerta M, Ochani M, Ochani K, Yang LH, Hudson L, Lin X, Patel N, Johnson SM, Chavan S, Goldstein RS, Czura CJ, Miller EJ, Al-Abed Y, Tracey KJ, Pavlov VA. et al. Modulation of TNF release by choline requires alpha7 subunit nicotinic acetylcholine receptormediated signaling. Mol Med 2008;14(9-10):567-574.

[50] Ilcol YO, Yilmaz Z, Cansev M, Ulus IH. Choline or CDP-choline alters serum lipid responses to endotoxin in dogs and 
rats: Involvement of the peripheral nicotinic acetylcholine receptors. Shock 2009;32(3):286-294.

[51] Pan Z-Y, Wang H. Synergistic interaction between choline and aspirin against acute inflammation induced by carrageenan and lipopolysaccharide. Int Immunopharmacol 2014;20:229 237.

[52] Li XD, Buccafusco JJ. Role of $\alpha 7$ Nicotinic Acetylcholine Receptors in the Pressor Response to Intracerebroventricular Injection of Choline: Blockade by Amyloid Peptide A 1 1-42. J Pharmacol Exp Ther. 2004;309(3):1206-1212.

[53] Yilmaz Z, Eralp Inan O, Kocaturk M, Baykal AT, Hacariz O, Hatipoglu I, Tvarijonaviciute A, Cansev M, Ceron J, Ulus IH. Changes in serum proteins after endotoxin administration in healthy and choline-treated calves. BMC Vet Res 2016;12:210

[54] Yilmaz S, Coskun C, Yalcin M, Savci V. CDP-Choline Prevents Cardiac Arrhythmias and Lethality Induced by Short-Term Myocardial Ischemia-Reperfusion Injury in the Rat: Involvement of Central Muscarinic Cholinergic Mechanisms. NaunynSchmiedeberg's archives of pharmacology 2008;378:293-301.

[55] Coskun C, Avci B, Yalcin M, Yermezler A, Yilmaz S, Savci V. Protective effect of CDP-choline on ischemia-reperfusioninduced myocardial tissue injury in rats. Ir J Med Sci 2013;183:539-548.

[56] Schmidt K, Frederick Hernekamp J, Doerr M, Zivkovic AR, Brenner T, Walther A, Weigand MA, Hofer S. Cytidine-5diphosphocholine reduces microvascular permeability during experimental endotoxemia. BMC Anesthesiol 2015;15:114122.

[57] Sevim Ç, Altinbas B, Yalcin M, Inan S, Ozyigit MO, Arican I, Yilmaz MS. Protective effect of CDP-choline on hypotension and tissue injury in septic shock model. Ankara Üniv Vet Fak Der. 2017;64:103-110.

[58] IIcol YO, Yilmaz Z, Ulus IH. Endotoxin alters serum-free choline and phospholipid-bound choline concentrations, and choline administration attenuates endotoxin-induced organ injury in dogs. Shock 2005;24(3):288-293.

[59] Pereira MR, Leite PEC. The Involvement of Parasympathetic and Sympathetic Nerve in the Inflammatory Reflex. J Cell Physiol 2016;231(9):1862-1869.

[60] Singh PM, Reid K, Gaddam R, Bhatia M, Smith S, Jacob A Chambers $P$. Effect of choline chloride premedication on xylazine-induced hypoxaemia in sheep. Vet Anaesth Analg 2017;44(5):1149-1155.

[61] Thomsen MS, Mikkelsen JD. The $\alpha 7$ nicotinic acetylcholine receptor ligands methyllycaconitine, NS6740 and GTS21 reduce lipopolysaccharide-induced TNF- $\alpha$ release from microglia. J Neuroimmunol 2012;251(1):65-72.

[62] Wang $H$, Yu M, Ochani M, Amella CA, Tanovic M, Susarla $S$, $\mathrm{Li} \mathrm{JH}$, Wang $\mathrm{H}$, Yang $\mathrm{H}$, Ulloa L, Al-Abed Y, Czura CJ, Tracey KJ. Nicotinic acetylcholine receptor $\alpha 7$ subunit is an essential regulator of inflammation. Nature 2002;421:384.

[63] Skok M, Grailhe R, Agenes F, Changeux J-P. The Role of Nicotinic Receptors in B-Lymphocyte Development and Activation. Life sciences 2007;80:2334-2336.

[64] De Rosa M, Esandi M, Garelli A, Rayes D, Bouzat C. Relationship between $\alpha 7 \mathrm{nAChR}$ and Apoptosis in Human Lymphocytes. Neuroimmunol 2005;160:154-161.

[65] Aicher A, Heeschen C, Mohaupt M, Cooke J, M Zeiher A, Dimmeler S. Nicotine Strongly Activates Dendritic CellMediated Adaptive Immunity: Potential Role for Progression of Atherosclerotic Lesions. Circulation 2003;107:604-611.
[66] Guinet E, Yoshida K, Nouri-Shirazi M. Nicotinic environment affects the differentiation and functional maturation of monocytes derived dendritic cells (DCs). Immunol Lett 2004;95(1):45-55.

[67] Venkatesan T, Choi Y-W, Lee J, Kim Y-K. Falcarindiol inhibits LPS-induced inflammation via attenuating MAPK and JAK-STAT signaling pathways in murine macrophage RAW 264.7 cells. Mol Cell Biochem 2018;445(1-2):169-178.

[68] De Simone R, Ajmone-Cat $M$, Carnevale D, Minghetti L. Activation of alpha7 nicotinic acetylcholine receptor by nicotine selectively up-regulates cyclooxygenase- 2 and prostaglandin E2 in rat microglial cultures. J Neuroinflammation. 2005;2:413.

[69] Sopori ML, Kozak W, Savage SM, Geng Y, Soszynski D, Kluger MJ, Perryman EK, Snow GE. Effect of nicotine on the immune system: Possible regulation of immune responses by central and peripheral mechanisms. Psychoneuroendocrinol 1998;23(2):189-204.

[70] Albuquerque EX, Pereira EFR, Alkondon M, Rogers SW. Mammalian nicotinic acetylcholine receptors: from structure to function. Physiol Rev 2009;89(1):73-120

[71] Shen J, Yakel JL. Nicotinic acetylcholine receptor-mediated calcium signaling in the nervous system. Acta Pharmacol Sin 2009;30(6):673-680.

[72] Bagdas D, Wilkerson JL, Kulkarni A, Toma W, AlSharari S, Gul Z, Lichtman AH, Papke RL, Thakur GA, Damaj MI. The $\alpha 7$ nicotinic receptor dual allosteric agonist and positive allosteric modulator GAT107 reverses nociception in mouse models of inflammatory and neuropathic pain. Br J Pharmacol 2016;173:2506-2520

[73] Resende RR, Adhikari A. Cholinergic receptor pathways involved in apoptosis, cell proliferation and neuronal differentiation. Cell Commun Signal 2009;7(1):20.

[74] Báez-Pagán CA, Delgado-Vélez $M$, Lasalde-Dominicci JA. Activation of the Macrophage $\alpha 7$ Nicotinic Acetylcholine Receptor and Control of Inflammation. J Neuroimmune Pharmacol 2015;10:468-476.

[75] Horenstein NA, Papke RL. Anti-inflammatory Silent Agonists. ACS Med Chem Lett 2017;8:989-991.

[76] Skok M. Editorial: To Channel or Not to Channel? Functioning of Nicotinic Acetylcholine Receptors in Leukocytes. J Leukocyte Biol 2009;86:1-3

[77] Villiger Y, Szanto I, Jaconi S, Blanchet C, Buisson B, Krause $\mathrm{KH}$, Bertrand D, Romand JA. Expression of an $\alpha 7$ Duplicate Nicotinic Acetylcholine Receptor-Related Protein in Human Leukocytes. J Neuroimmunol 2002;126:86-98.

[78] Panchal JL. Dual Signaling Modes of Alpha7 Nicotinic Acetylcholine Receptors ( $\alpha 7 \mathrm{nAChRs}$ ). Annals of Experimental and Molecular Biology 2018;1:1-2.

[79] Kabbani N, Nichols RA. Beyond the Channel: Metabotropic Signaling by Nicotinic Receptors. Trends Pharmacol Sci 2018;39:354-366.

[80] Kwon DH, Cha HJ, Choi EO, Leem SH, Kim GY, Moon SK, Chang YC, Yun SJ, Hwang HJ, Kim BW, Kim WJ, Choi YH. Schisandrin A suppresses lipopolysaccharide-induced inflammation and oxidative stress in RAW 264.7 macrophages by suppressing the NF-KB, MAPKs and PI3K/Akt pathways and activating Nrf2/ HO-1 signaling. Int J Mol Med 2018;41:264-274.

[81] Li X, Su J, Cui X, Li Y, Barochia A, Eichacker PQ. Can we predict the effects of NF-kappaB inhibition in sepsis? Studies with 
parthenolide and ethyl pyruvate. Expert Opin Investig Drugs 2009;18:1047-1060.

[82] Marrero MB, Bencherif M. Convergence of Alpha 7 Nicotinic Acetylcholine Receptor-Activated Pathways for Anti-Apoptosis and Anti-Inflammation: Central Role for JAK2 Activation of STAT3 and NF-kB. Brain Res 2008;1256:1-7

[83] Tsurutani J, Castillo SS, Brognard J, Granville CA, Zhang C, Gills JJ, Sayyah J, Dennis PA.et al. Tobacco components stimulate Akt-dependent proliferation and NFKB-dependent survival in lung cancer cells. Carcinogenesis. 2005;26:1182-1195.

[84] Wang $H$, Liao $H$, Ochani $M$, Justiniani $M$, Lin $X$, Yang L, AlAbed $\mathrm{Y}$, Wang $\mathrm{H}$, Metz $\mathrm{C}$, Miller EJ, Tracey KJ, Ulloa L. et al. Cholinergic agonists inhibit HMGB1 release and improve survival in experimental sepsis. Nat Med 2004;10:1216-1221.

[85] Chatterjee PK, Al-Abed Y, Sherry B, Metz CN. Cholinergic agonists regulate JAK2/STAT3 signaling to suppress endothelial cell activation. Am J Physiol Physiol 2009;297:C1294-C1306.

[86] Williams LM, Ricchetti G, Sarma U, Smallie T, M J Foxwell B. Interleukin-10 Suppression of Myeloid Cell Activation - A Continuing Puzzleç Immunology 2004;113:281-292.

[87] Levy DE, Lee $C$. What does Stat3 do? J Clin Invest 2002;109(9):1143-1148.

[88] Peña G, Cai B, Deitch EA, Ulloa L. JAK2 inhibition prevents innate immune responses and rescues animals from sepsis. J Mol Med (Berl) 2010;88(8):851-859.

[89] Lee S Bin, Lee WS, Shin JS, Jang DS, Lee KT. Xanthotoxin suppresses LPS-induced expression of iNOS, COX-2, TNF- $\alpha$, and IL-6 via AP-1, NF-KB, and JAK-STAT inactivation in RAW 264.7 macrophages. Int Immunopharmacol 2017;49(May):21-29.

[90] Engblom D, Saha S, Engström L, Westman M, Audoly LP, Jakobsson PJ, Blomqvist A. Microsomal prostaglandin E synthase- 1 is the central switch during immune-induced pyresis. Nat Neurosci 2003;6:1137.

[91] Hata AN, Breyer RM. Pharmacology and signaling of prostaglandin receptors: Multiple roles in inflammation and immune modulation. Pharmacol Ther 2004;103(2):147-166.
[92] Noda M, Kariura Y, Pannasch U, Nishikawa K, Wang L, Seike $T$, Ifuku $M$, Kosai $Y$, Wang $B$, Nolte $C$, Aoki $S$, Kettenmann $H$, Wada K. Neuroprotective role of bradykinin because of the attenuation of pro-inflammatory cytokine release from activated microglia. J Neurochem 2007;101:397-410.

[93] Ricciotti E, FitzGerald GA. Prostaglandins and inflammation. Arterioscler Thromb Vasc Biol 2011;31(5):986-1000.

[94] Smyth EM, Grosser T, Wang M, Yu Y, FitzGerald GA. Prostanoids in health and disease. J Lipid Res 2009;50 Suppl(Suppl):S423-S428.

[95] Langenbach R, Loftin C, Lee C, Tiano H. Cyclooxygenase knockout mice: Models for elucidating isoform-specific functions. Biochem Pharmacol 1999;58(8):1237-1246.

[96] Choi JS, Nurul Islam M, Yousof Ali M, Kim EJ, Kim YM, Jung HA. Effects of C-glycosylation on anti-diabetic, anti-Alzheimer's disease and anti-inflammatory potential of apigenin. Food Chem Toxicol 2014;64:27-33.

[97] Tajima T, Murata T, Aritake K, Urade Y, Michishita M, Matsuoka T, Narumiya S, Ozaki H, Hori M. EP2 and EP4 receptors on muscularis resident macrophages mediate LPS-induced intestinal dysmotility via iNOS upregulation through CAMP/ERK signals. AJP Gastrointest Liver Physiol 2012;302(5):G524-G534.

[98] Arrigoni E, Avéret N, Cohadon F. Effects of CDP-choline on phospholipase A2 and cholinephosphotransferase activities following a cryogenic brain injury in the rabbit. Biochem Pharmacol 1987;36:3697-3700.

[99] Ezoulin MJM, Liu Z, Dutertre-Catella H, Wu G, Dong $\mathrm{CZ}$, Heymans F, Ombetta JE, Rat P, Massicot F. A new acetylcholinesterase inhibitor with anti-PAF activity modulates oxidative stress and pro-inflammatory mediators release in stimulated RAW 264.7 macrophage cells. Comparison with tacrine. Int Immunopharmacol 2008; 7:1685-1694.

[100]Zhang J, Rivest S. Anti-inflammatory effects of prostaglandin E2 in the central nervous system in response to brain injury and circulating lipopolysaccharide. J Neurochem 2001;76:855864. 